May 8, 2012

Mr. John Glenn

U.S. Department of Energy

Oak Ridge Office

P.O. Box 2001

Oak Ridge, TN 37831-0117

DOE CONTRACT NO. DE-AC05-06OR23100

SUBJECT: INDEPENDENT VERIFICATION OF THE BUILDING 3550 SLAB AT OAK RIDGE NATIONAL LABORATORY, OAK RIDGE, TENNESSEE DCN 5086-SR-01-0

Dear Mr. Glenn:

The Oak Ridge Institute for Science and Education (ORISE) has completed the independent verification survey of the Building 3550 Slab. The results of this effort are provided in the enclosed final report.

Please direct any additional questions you may have to me via my information below, Evan Harpenau at 865.241.8793, or Kathy Rollow at 865.574.4390.

Sincerely,

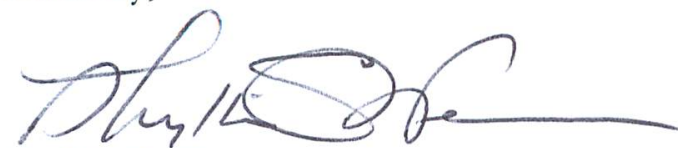

Phyllis C. Weaver

Health Physicist Project Manager

Survey Projects

PCW:fr

Enclosure

c:

L. Mezga, UT-B/ORNL

D. VanHoesen, UT-B/ORNL

C. Johnson, BJC

electronic: $\quad$ S. Roberts, ORISE

T. Vitkus, ORISE

$\mathrm{K}$. Rollow, ORISE

E. Bailey, ORISE

E. Harpenau, ORISE

File/5086 


\section{INDEPENDENT VERIFICATION OF THE BUILDING 3550 SLAB AT OAK RIDGE NATIONAL LABORATORY OAK RIDGE, TENNESSEE}

P. C. Weaver

Prepared for

U.S. Department of Energy

OR I S E

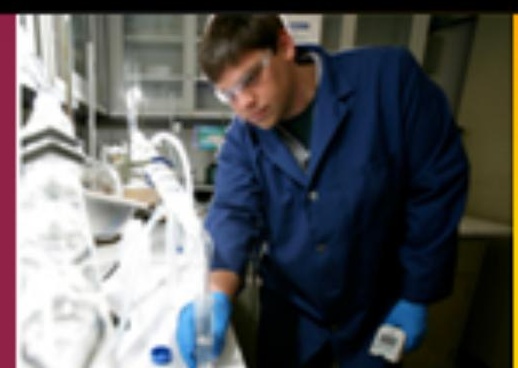

Approved for public release; further dissemination unlimited. 
The Oak Ridge Institute for Science and Education (ORISE) is a U.S. Department of Energy facility focusing on scientific initiatives to research health risks from occupational hazards, assess environmental cleanup, respond to radiation medical emergencies, support national security and emergency preparedness, and educate the next generation of scientists. ORISE is managed by Oak Ridge Associated Universities (ORAU).

\section{NOTICES}

The opinions expressed herein do not necessarily reflect the opinions of the sponsoring institutions of Oak Ridge Associated Universities.

This report was prepared as an account of work sponsored by the United States Government. Neither the United States Government nor the U.S. Department of Energy, nor any of their employees, makes any warranty, expressed or implied, or assumes any legal liability or responsibility for the accuracy, completeness, or usefulness of any information, apparatus, product, or process disclosed, or represents that its use would not infringe on privately owned rights. Reference herein to any specific commercial product, process, or service by trade name, mark, manufacturer, or otherwise, does not necessarily constitute or imply its endorsement or recommendation, or favor by the U.S. Government or any agency thereof. The views and opinions of authors expressed herein do not necessarily state or reflect those of the U.S. Government or any agency thereof. 


\title{
INDEPENDENT VERIFICATION OF THE BUILDING 3550 SLAB \\ AT THE OAK RIDGE NATIONAL LABORATORY \\ OAK RIDGE, TENNESSEE
}

\author{
Prepared by \\ P. C. Weaver \\ Oak Ridge Institute for Science and Education \\ Oak Ridge, Tennessee 37831-0117

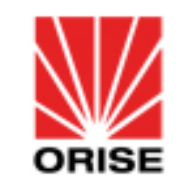

Prepared for the

U.S. Department of Energy

FINAL REPORT

MAY 2012

This report is based on work performed by the Oak Ridge Institute for Science and Education under contract number DE-AC05-06OR23100 with the U.S. Department of Energy 


\section{INDEPENDEN'T VERIFICATION OF THE BUILDING 3550 SLAB AT THE OAK RIDGE NATIONAL LABORATORY \\ OAK RIDGE, TENNESSEE}

\section{FINAL REPORT}

Prepared by:

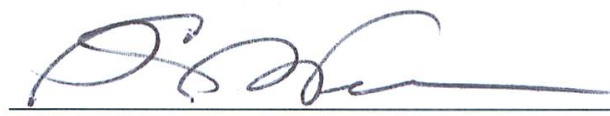

Date: $5 / 8 / 12$

P. C. Weaver, Project Manager

Independent Environmental Assessment and Verification
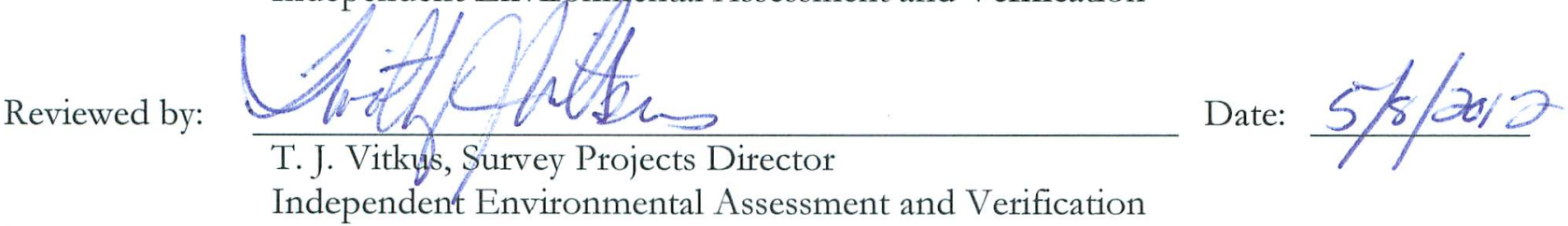

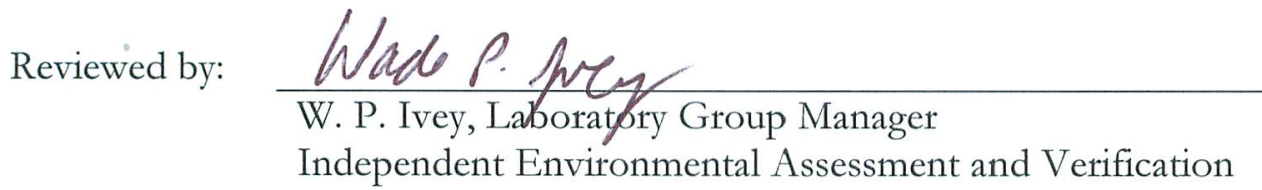

Date:

$5 / 6 / 12$

Reviewed by:

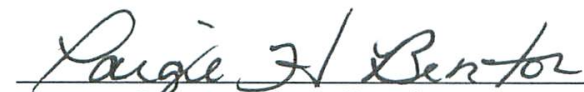

P. H. Benton, Quality Assurance Specialist

Independent Environmental Assessment and Verification

Approved for

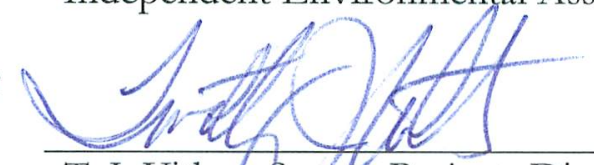

Date:

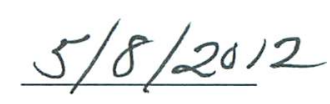

release by:

T. J. Vitkus, Survey Projects Director

Independert Environmental Assessment and Verification

Date: 


\section{CONTENTS}

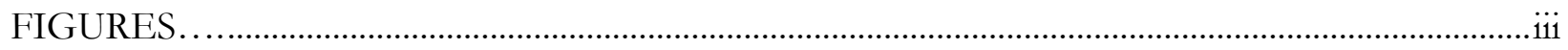

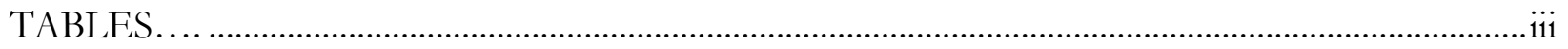

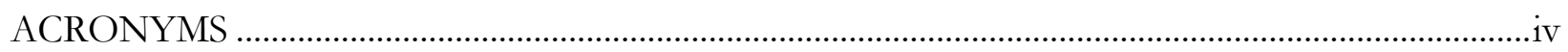

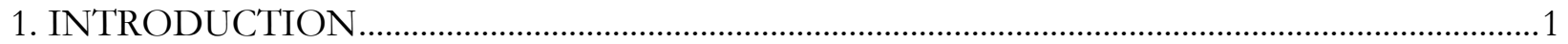

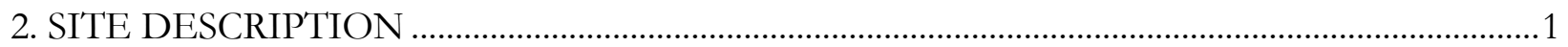

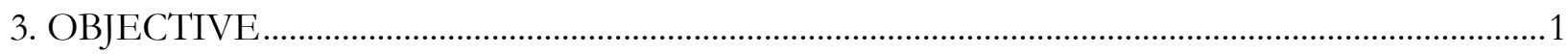

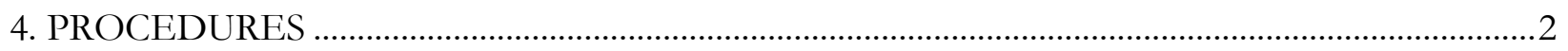

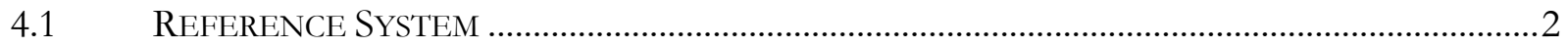

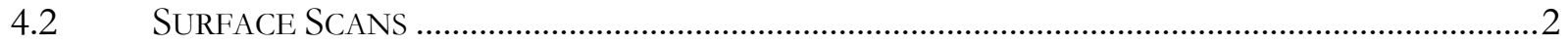

S.3 SURFACE ACTIVITY MEASUREMENTS .................................................................................

4.4 SAMPLE ANALYSIS AND DATA INTERPRETATION ...................................................................

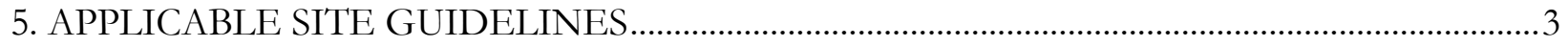

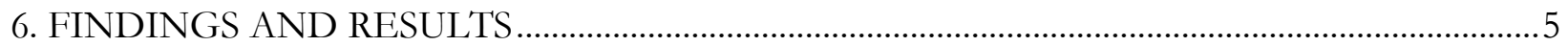

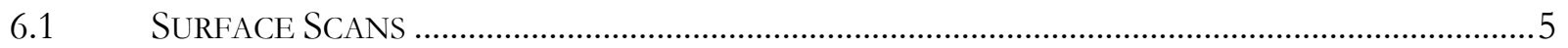

6.2 SURFACE ACTIVITY MEASUREMENTS .......................................................................................

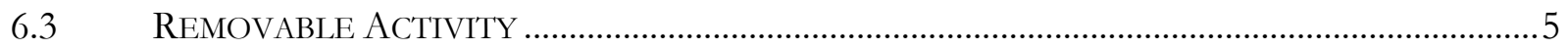

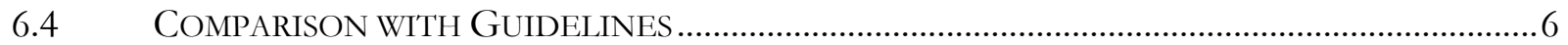

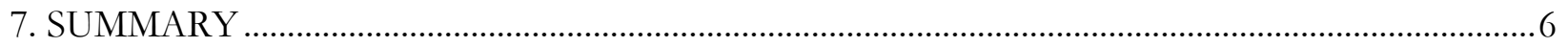

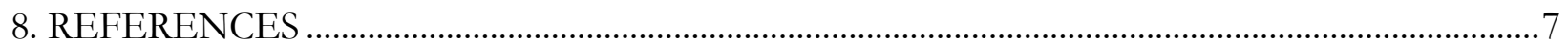

APPENDIX A FIGURES

APPENDIX B TABLES

APPENDIX C MAJOR INSTRUMENTATION

APPENDIX D SURVEY AND ANALYTICAL PROCEDURES 


\section{FIGURES}

Figure A-1: Overview of Oak Ridge National Laboratory Central Campus....................................... A-1

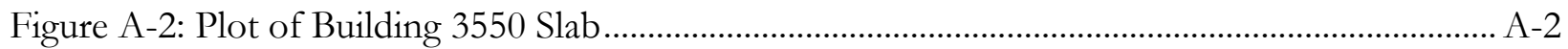

Figure A-3: Former Building 3550 Floor Plan ................................................................................... A-3

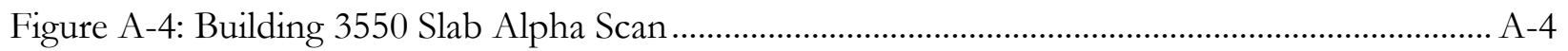

Figure A-5: Building 3550 Slab Alpha Plus Beta Scan ................................................................... A-5

Figure A-6: Building 3550 Slab Gamma Scan ................................................................................... A-6

Figure A-7: Building 3550 Slab Measurement and Sample Locations .................................................. A-7

\section{TABLES}

Table B-1. Surface Activity for the Building 3550 Slab...................................................................... 


\section{ACRONYMS}

$\begin{array}{ll}\text { BKG } & \text { background } \\ \mathrm{cm} & \text { centimeter } \\ \mathrm{cpm} & \text { counts per minute } \\ \text { DOE } & \text { U.S. Department of Energy } \\ \text { dpm } / 100 \mathrm{~cm}^{2} & \text { disintegration per minute per } 100 \text { square centimeters } \\ \text { ELCR } & \text { excess lifetime cancer risk } \\ \text { HPS } & \text { Health Physics Society } \\ \text { in } & \text { inch } \\ \text { IV } & \text { independent verification } \\ \text { NaI } & \text { sodium iodide } \\ \text { ORNL } & \text { Oak Ridge National Laboratory } \\ \text { ORAU } & \text { Oak Ridge Associated Universities } \\ \text { ORISE } & \text { Oak Ridge Institute for Science and Education } \\ \text { ROD } & \text { Record of Decision } \\ \text { VSP } & \text { Visual Sample Plan }\end{array}$




\section{INDEPENDENT VERIFICATION OF THE BUILDING 3550 SLAB AT THE OAK RIDGE NATIONAL LABORATORY OAK RIDGE, TENNESSEE}

\section{INTRODUCTION}

Building 3550, located at the Oak Ridge National Laboratory (ORNL), was constructed in 1943 as part of the original Clinton Engineering Works and served as the plant's main laboratory building. The facility was used primarily for processing irradiated fuel elements and thorium oxycarbonate; however, it may have been involved in fluoride volatility studies. Building 3550 was used in later years for the cleaning and management of face masks and respirators (UT-B 2008). The original $14,036-\mathrm{ft}^{2}$ structure was primarily of wood construction on a poured concrete slab foundation. The building structure has recently been removed leaving the slab foundation in-place.

The radiological inventory included ${ }^{137} \mathrm{Cs},{ }^{90} \mathrm{Sr},{ }^{232} \mathrm{Th},{ }^{235} \mathrm{U},{ }^{238} \mathrm{U}{ }^{239 / 240} \mathrm{Pu}$, and ${ }^{241} \mathrm{Am}$ (ORISE 2010). The U.S. Department of Energy (DOE) requires that the "as left" status of the slab condition be verified to ensure that the residual radioactivity is less than the guidance provided in the Bethel Valley Record of Decision (ROD) (DOE 2002). At the request of DOE-Oak Ridge Office, ORISE has been tasked with conducting independent verification of the remaining building slab.

\section{SITE DESCRIPTION}

ORNL is located in Oak Ridge, Tennessee approximately 25 miles west of Knoxville at the western end of Bethel Valley Road. The site occupies approximately 10,000 acres of the Oak Ridge Reservation and is bounded to the south by the Clinch River and to the north by Bethel Valley Road (Figure A-1). The remaining Building 3550 Slab is located on Central Avenue in the central portion of the main campus between Third and Fifth Streets (Figure A-2). The first floor plan of Building 3550 indicates numerous laboratories particularly along the southern wing of the building (Figure A-3).

\section{OBJECTIVE}

The objective of this verification survey is to provide independent review and field assessment of remediation actions conducted by Safety and Ecology Corporation (SEC) to document that the final 
radiological condition of the slab meets the release guidelines as referenced in the Bethel Valley ROD. ORISE will compare surface activity measurement data to the ROD and any removable activity identified to the DOE Order 458.1 which references DOE Order 5400.5 for allowable alpha and beta removable activity (DOE 1993, 2002 and 2011).

\section{PROCEDURES}

ORISE conducted verification survey activities on the Building 3550 Slab from July 26, 2011 through July 28, 2011. ORISE survey activities were performed in accordance with the final Project Specific Plan for Independent Verification of Building Slabs at ORNL (ORISE 2011a). Procedures supporting the field implementation of the plan were obtained from the Independent Environmental Assessment and Verification Program Survey Procedures Manual and the Oak Ridge Associated Universities (ORAU) Quality Program Manual (ORISE 2008 and ORAU 2011a).

\subsection{REFERENCE SYSTEM}

Building dimensions were obtained using a hand-held distance meter to establish coordinate locations. The coordinates were then used for identifying sampling and measurement locations. Scan and measurement data were manually recorded and referenced to either a specific coordinate or prominent site feature.

\subsection{SURFACE SCANS}

High density scans were performed for alpha, alpha plus beta, and gamma radiation on the slab surface that had not been covered with new concrete. Particular attention was given to areas with the highest potential for contamination (i.e., cracks, joints, and surface run-off pathways). A large area gas proportional detector $\left(550 \mathrm{~cm}^{2}\right)$ was used for alpha and alpha plus beta radiation and a 2 inch $\times 2$ inch sodium iodide, thallium-activated $[\mathrm{NaI}(\mathrm{Tl})]$ detector was used to detect gamma radiation. All detectors were coupled to ratemeter-scalers with audible indicators. ORISE field personnel relied on the audio output to identify any locations of elevated direct radiation that might suggest the presence of residual contamination. Locations of elevated direct radiation that potentially exceeded surface contamination guidelines were marked and identified for further investigation (Figures A-4 to A-6). 


\subsection{Surface ACtivity MEASUREMENTS}

Static measurements for alpha and alpha plus beta activity were performed at 12 randomly generated locations. An additional 21 judgmental locations were identified for measurements and sampling where surface scans identified radiation levels potentially above acceptable surface contamination guidelines (Figure A-7). These predetermined random field assessment locations were designed and generated based on a statistical sampling design facilitated by using Visual Sample Plan (VSP) software (version 6.0 or greater). Data quality assessment was performed in accordance with U.S. Environmental Protection Agency (EPA) QA/G-9R Data Quality Assessment: A Reviewer's Guide and EPA QA/G-9S Guidance for Data Quality Assessment (EPA 2006a and b).

Smears for removable gross alpha and beta contamination were obtained on the original concrete surface. A $47 \mathrm{~mm}$ diameter numbered filter paper disk was used to sample an area of $100 \mathrm{~cm}^{2}$.

\subsection{SAMPLE ANALYSIS AND DATA INTERPRETATION}

Smear samples and data were returned to the ORISE facility in Oak Ridge, Tennessee for analysis and interpretation. Smears were analyzed for removable gross alpha and beta in accordance with the ORISE Laboratory Procedures Manual (ORISE 2011b). A low background proportional counter was used to determine gross activity levels. Smear and direct measurement results are reported in units of disintegration per minute per 100 square centimeters $\left(\mathrm{dpm} / 100 \mathrm{~cm}^{2}\right)$. Data collected as part of this survey will be archived by ORISE.

\section{APPLICABLE SITE GUIDELINES}

For structural surfaces that may remain in place, the "as left" condition must meet industrial surface criteria derived to achieve the same average excess lifetime cancer risk (ELCR) of $1 \times 10^{-4}$ and the maximum risk level at ten times the average, as specified for the industrial area soils, as defined in the Bethel Valley ROD. The industrial surface criteria are applicable to the entire exposed surface of the slab (DOE 2002).

Surface criteria sited in the Bethel Valley ROD have been derived based on American National Standard Institute /Health Physics Society (HPS) HPS N13.12-1999 (HPS 1999). This standard specifies screening levels for clearance of surfaces containing residual radioactive materials, based on 
a dose limit of $1 \mathrm{mrem} /$ year, for several groups of radionuclides. Clearance, as defined by the standard, is "the removal of items or materials that contain residual levels of radioactive materials within authorized practices from any further control of any kind" (DOE 2002). The primary radionuclides of concern specified for building surfaces in Bethel Valley are classified in Group 2 per the Standard (DOE 2002). This includes uranium and selected high dose beta-gamma emitters. However, recent characterization data indicate Group 1 radionuclides radium, thorium, and transuranics $\left({ }^{232} \mathrm{Th},{ }^{239 / 240} \mathrm{Pu}\right.$, and $\left.{ }^{241} \mathrm{Am}\right)$ are present in the radionuclide mix. The surface activity screening level for Group 1 radionuclides is specified at $600 \mathrm{dpm} / 100 \mathrm{~cm}^{2}$ and Group 2 radionuclides is specified at $6,000 \mathrm{dpm} / 100 \mathrm{~cm}^{2}$ (HPS 1999). This screening level has been used to derive a risk-based surface concentration limit as follows (DOE 2002):

RLsurf $=\mathrm{TR} /[\mathrm{DL} / \mathrm{SL} \times \mathrm{R} \times \mathrm{ED}]=1 \times 10^{-4} \mathrm{ELCR} /\left[(1 \mathrm{mrem} / \mathrm{yr}) /\left(6,000 \mathrm{dpm} / 100 \mathrm{~cm}^{2}\right) \times\right.$ $6 \times 10^{-7} \mathrm{ELCR} / \mathrm{mrem} \times 25$ years $]=40,000 \mathrm{dpm} / 100 \mathrm{~cm}^{2}$, where:

- $\quad$ RLsurf = remediation levels for residual building surfaces,

- $\mathrm{TR}=$ target risk level $=1 \times 10^{-4}$ ELCR,

- $\mathrm{DL}=$ dose limit used to derive surface screening level $=1 \mathrm{mrem} /$ year

- $\mathrm{SL}=$ surface activity screening level for Group 2 radionuclides $=6,000 \mathrm{dpm} / 100 \mathrm{~cm}^{2}$

- $\mathrm{R}=$ cancer risk per unit dose for surface-deposited radioactivity (conservatively based on radionuclide-specific slope factor and external dose coefficient for $\left.{ }^{137} \mathrm{Cs}+\mathrm{D}\right)=6 \times 10^{-7}$ $\mathrm{ELCR} / \mathrm{mrem}$

- $\quad \mathrm{ED}=$ exposure duration $=25$ years for industrial scenario.

NOTE: The derived RLsurf value is based on the assumption that a worker could potentially be located directly above the building surfaces for 2,000 hours per year. Since it is unlikely that any worker would actually occupy this location for such an extended period of time, this estimate is considered conservative and any actual risk may be well below the target level of $1 \times 10^{-4}$ ELCR. Additional conservative assumptions are the absence of any consideration of (1) the decreasing concentrations of radionuclides on the building surfaces due to radioactive decay, and (2) shielding effects from backfill of basements and other subsurface structures (DOE 2002). 


\section{FINDINGS AND RESULTS}

\subsection{SURFACE SCANS}

Surface scans were performed over the entire pad with the exception of areas that had been covered with new concrete. Alpha activity scans ranged from $0 \mathrm{cpm}$ to 17,000 cpm and alpha plus beta activity scans ranged from 3,000 cpm to $57,000 \mathrm{cpm}$. Gamma activity scans over the surface of the slab ranged from $30,000 \mathrm{cpm}$ to $95,000 \mathrm{cpm}$. This scan data is used as a qualitative indication to identify areas with radioactivity levels that require additional investigations (Figures A-4 to A-6). Static measurements are required to provide a quantitative determination of the guideline acceptance criteria. Much of the elevated radioactivity was identified in what would have been primarily laboratory areas in the southern wing of the building. This included rooms 19, 19B, 21, 21 A, 23, 24, 24A, 25, 25A, 26, 27, 27A, 28, 28A, 28B, 29, 30, 31, 32, 32A, 34, and 36 (Figure A-3). Surveyors noted that cracks and joint areas in the slab had higher activity levels.

\subsection{Surface ACtivity Measurements}

Static surface measurements were obtained for alpha and alpha plus beta at each randomly generated and judgmental location. Surface activity measurements are presented in Table B-1. The net total activity is reported in $\mathrm{dpm} / 100 \mathrm{~cm}^{2}$ after subtracting gross ambient background from the gross static measurement count rate. Random generated measurements for alpha activity ranged from $49 \mathrm{dpm} / 100 \mathrm{~cm}^{2}$ to $610,000 \mathrm{dpm} / 100 \mathrm{~cm}^{2}$, and alpha plus beta measurements ranged from $560 \mathrm{dpm} / 100 \mathrm{~cm}^{2}$ to $290,000 \mathrm{dpm} / 100 \mathrm{~cm}^{2}$. Surface activity for judgmental locations for alpha activity ranged from $16 \mathrm{dpm} / 100 \mathrm{~cm}^{2}$ to $2,600 \mathrm{dpm} / 100 \mathrm{~cm}^{2}$ and alpha plus beta measurements ranged from $430 \mathrm{dpm} / 100 \mathrm{~cm}^{2}$ to $52,000 \mathrm{dpm} / 100 \mathrm{~cm}^{2}$. The highest activity measurement was sample location 5086R0006 collected in the area of what was once Room 28A.

\subsection{REMOVABLE ACTIVITY}

Removable alpha activity ranged from $-0.4 \mathrm{dpm} / 100 \mathrm{~cm}^{2}$ to $310 \mathrm{dpm} / 100 \mathrm{~cm}^{2}$ and removable beta activity ranged from $-2.6 \mathrm{dpm} / 100 \mathrm{~cm}^{2}$ to $9.9 \mathrm{dpm} / 100 \mathrm{~cm}^{2}$ for randomly generated sampling locations. Removable activity at judgmental locations ranged from $-0.4 \mathrm{dpm} / 100 \mathrm{~cm}^{2}$ to 28 $\mathrm{dpm} / 100 \mathrm{~cm}^{2}$ for alpha and $-4.7 \mathrm{dpm} / 100 \mathrm{~cm}^{2}$ to $19 \mathrm{dpm} / 100 \mathrm{~cm}^{2}$ for beta. 


\subsection{COMPARISON WITH GUIDELINES}

The remediation level guideline for Group 2 radionuclides is $40,000 \mathrm{dpm} / 100 \mathrm{~cm}^{2}$ for activity that can remain. This was exceeded at two locations for alpha plus beta; 5086R0006 (290,000 dpm/100 $\left.\mathrm{cm}^{2}\right)$ and 5086R0013 $\left(52,000 \mathrm{dpm} / 100 \mathrm{~cm}^{2}\right)$. This guidance is not specific as to the type of radiation. However, Group 1 radionuclides were present and identified in this facility during characterization efforts (ORISE 2010). The guideline for Group 1 radionuclides is 4,000 dpm/100 $\mathrm{cm}^{2}$.

Removable contamination activity levels were compared with the DOE Order 5400.5 guidance for acceptable activity levels because HPS N13.12-1999 does not provide remediation guidelines for removable activity. Allowable alpha removable surface activity per DOE Order 5400.5 is 20 $\mathrm{dpm} / 100 \mathrm{~cm}^{2}$. Based on the results, removable alpha contamination was identified at locations 5086R0006 (310 dpm/100 $\left.\mathrm{cm}^{2}\right), 5086 \mathrm{R} 0009$ (45 dpm/100 cm²), 5086R0055 (19 dpm/100 cm²) and 5086R0056 (28 dpm/100 $\left.\mathrm{cm}^{2}\right)$. Three of the four locations exceeded the $20 \mathrm{dpm} / 100 \mathrm{~cm}^{2}$ guidance while location $5086 \mathrm{R} 0055$ is just below at $19 \mathrm{dpm} / 100 \mathrm{~cm}^{2}$.

\section{SUMMARY}

During the period of July 26, 2011 through July 28, 2011, ORISE conducted verification survey activities on the Building 3550 Slab that included scans, measurements, and the collection of smears. Scans for alpha, alpha plus beta, and gamma activity identified several areas that were investigated. Two measurement locations exceeded the $40,000 \mathrm{dpm} / 100 \mathrm{~cm}^{2}$ surface remediation level guidelines and three measurements exceeded the DOE Order 5400.5 guidance for removable contamination. Although removable activity is not specifically addressed by the guidance in the Bethel Valley ROD, ORISE is of the opinion that the removable activity should be addressed by the contractor along with the surface measurements exceeding the guidance. 


\section{REFERENCES}

Health Physics Society (HPS). Surface and Volume Radioactivity Standards for Clearance. McLean, Virginia. August 31, 1999.

Oak Ridge Associated Universities (ORAU). Quality Program Manual for the Independent Environmental Assessment and Verification Program. Oak Ridge, Tennessee. May 10, 2011a.

Oak Ridge Associated Universities. ORAU Health and Safety Manual. Oak Ridge, Tennessee. March 24, 2011b.

Oak Ridge Institute for Science and Education (ORISE). Project-Specific Plan for the Independent Verification of Building Slab at Oak Ridge National Laboratory. Oak Ridge, Tennessee. 5086-PL-01-0. July 2011a.

Oak Ridge Institute for Science and Education. Survey Procedures Manual for the Independent Environmental Assessment and Verification Program. Oak Ridge, Tennessee.

May 2008.

Oak Ridge Institute for Science and Education. Data Sharing ORNL EMWMF. Oak Ridge, Tennessee. October 25, 2010.

Oak Ridge Institute for Science and Education. Laboratory Procedures Manual for the Independent Environmental Assessment and Verification Program. Oak Ridge, Tennessee. February 28, 2011b.

Oak Ridge Institute for Science and Education. Radiation Protection Manual. Oak Ridge, Tennessee. February 14, 2011c.

U.S. Department of Energy (DOE). Record of Decision for Interim Actions in Bethel Valley, Oak Ridge, Tennessee. May 2002.

U.S. Department of Energy. DOE Order 458.1, Chg 1, Radiation Protection of the Public and the Environment. Washington, D.C. March 8, 2011.

U.S. Department of Energy. DOE Order 5400.5 Radiation Protection of the Public and the Environment. Washington, DC. January 7, 1993.

U.S. Environmental Protection Agency (EPA). Data Quality Assessment: A Reviewer's Guide: QA/G-9R. Washington, DC. February 2006a.

U.S. Environmental Protection Agency. Data Quality Assessment: Statistical Methods for Practitioners. EPA QA/G-9S. Washington, DC. February $2006 \mathrm{~b}$.

UT-B 2008. Preliminary Hazard Screening for the 3550 Complex, Oak Ridge National Laboratory, Oak Ridge, Tennessee, PHS-OR-3550-Complex, Rev. 0, prepared for DOE-EM, February. 
APPENDIX A

FIGURES 


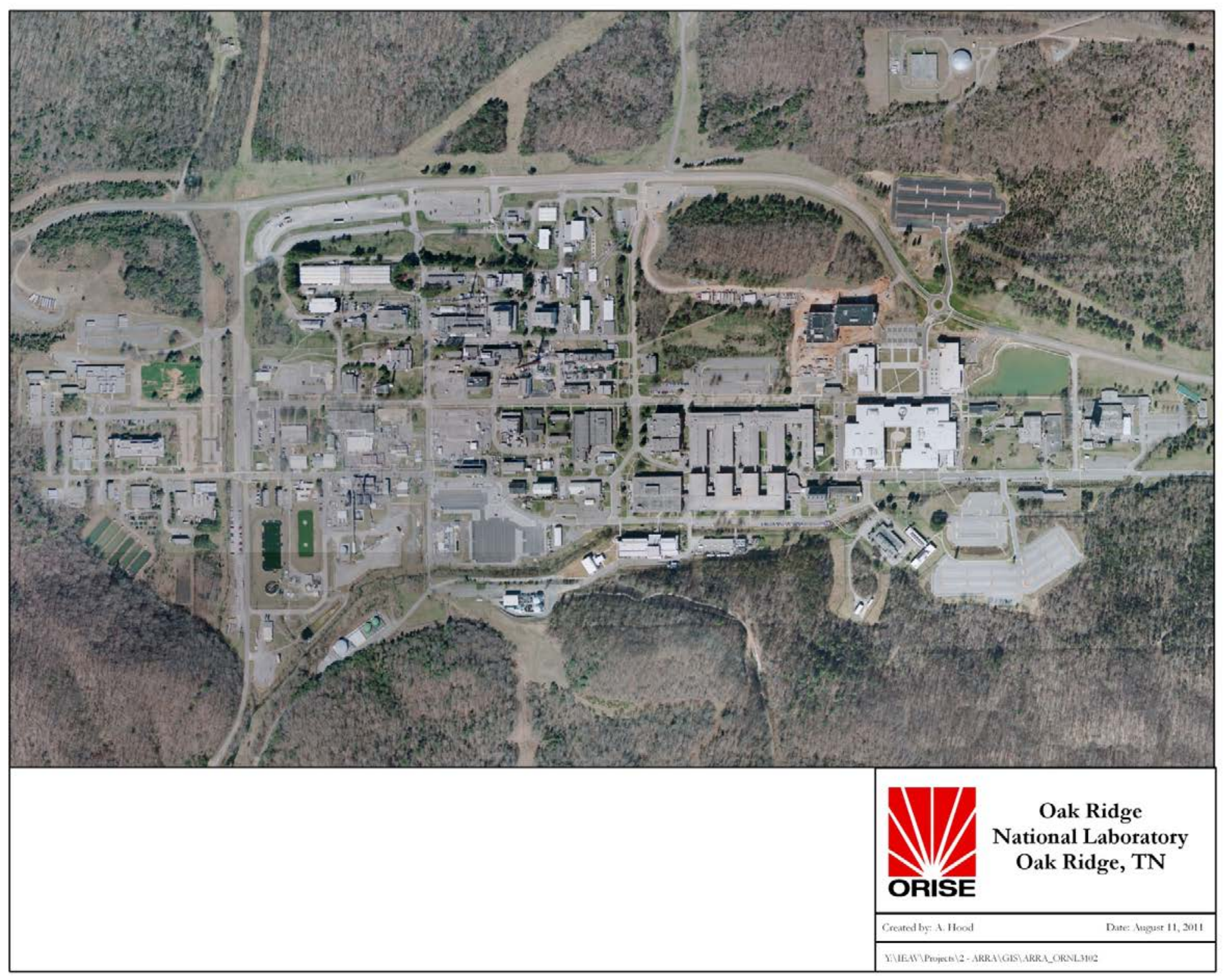

Figure A-1. Overview of Oak Ridge National Laboratory Central Campus 


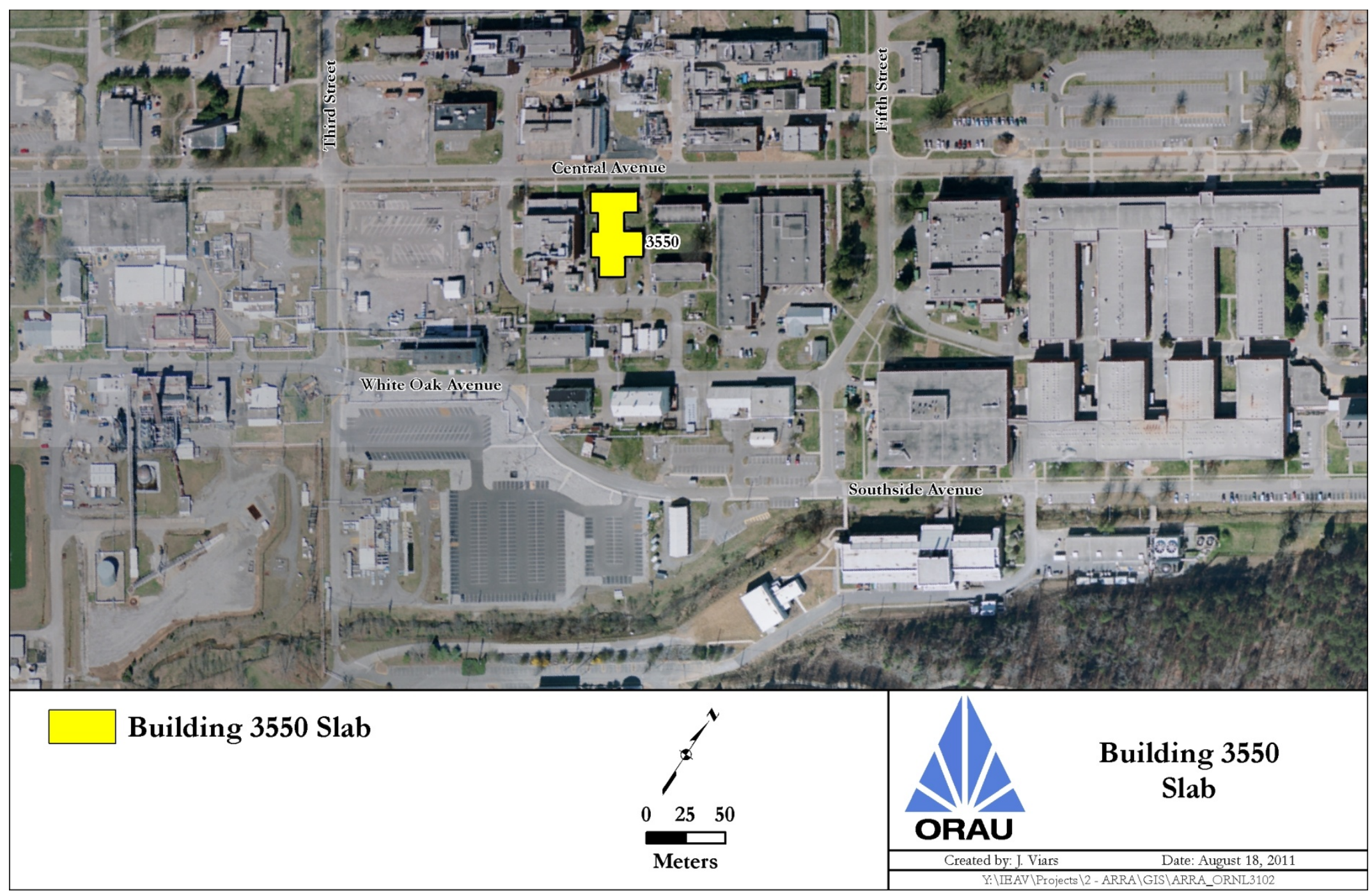

Figure A-2. Plot of Building 3550 Slab 


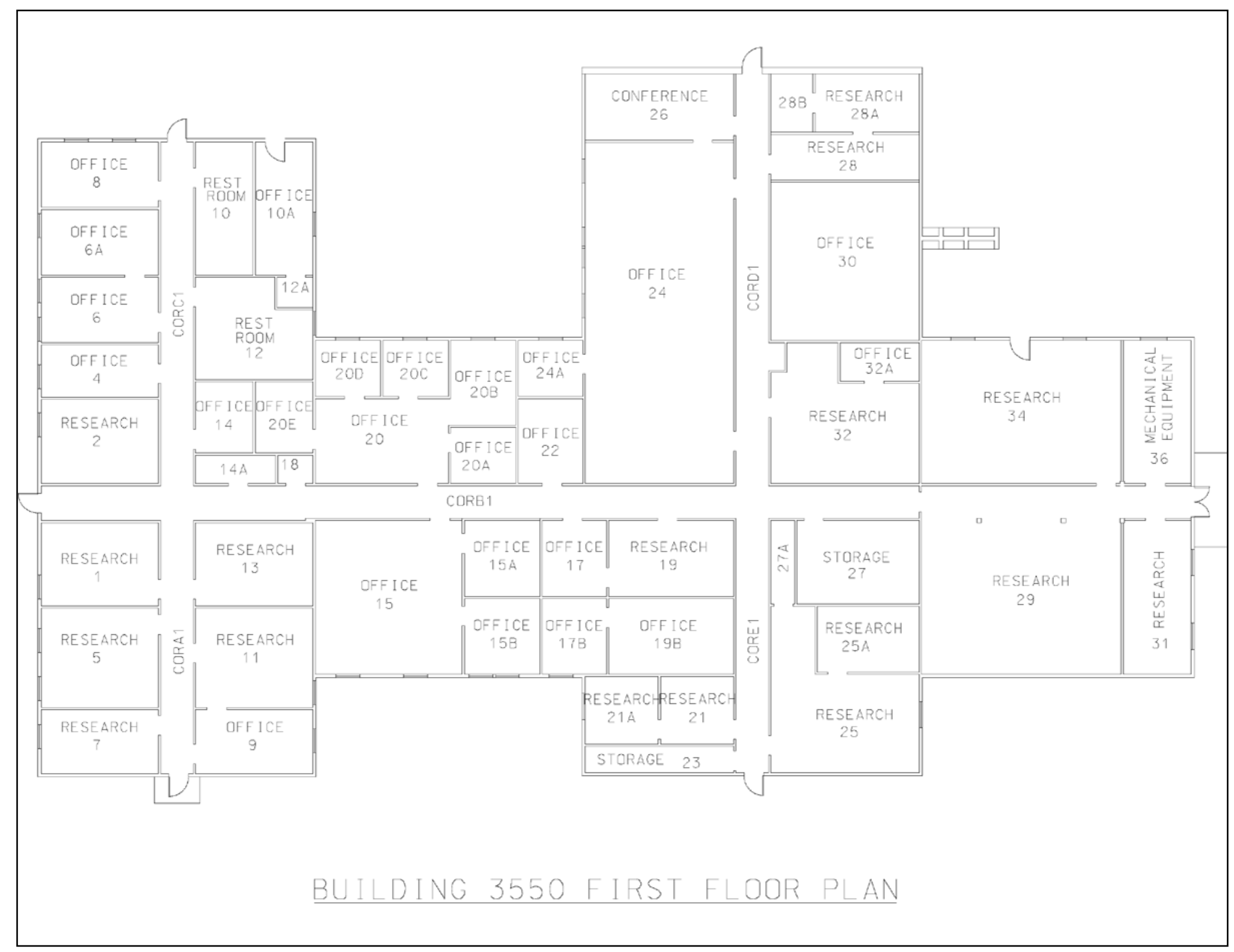

Figure A-3. Former Building 3550 Floor Plan 


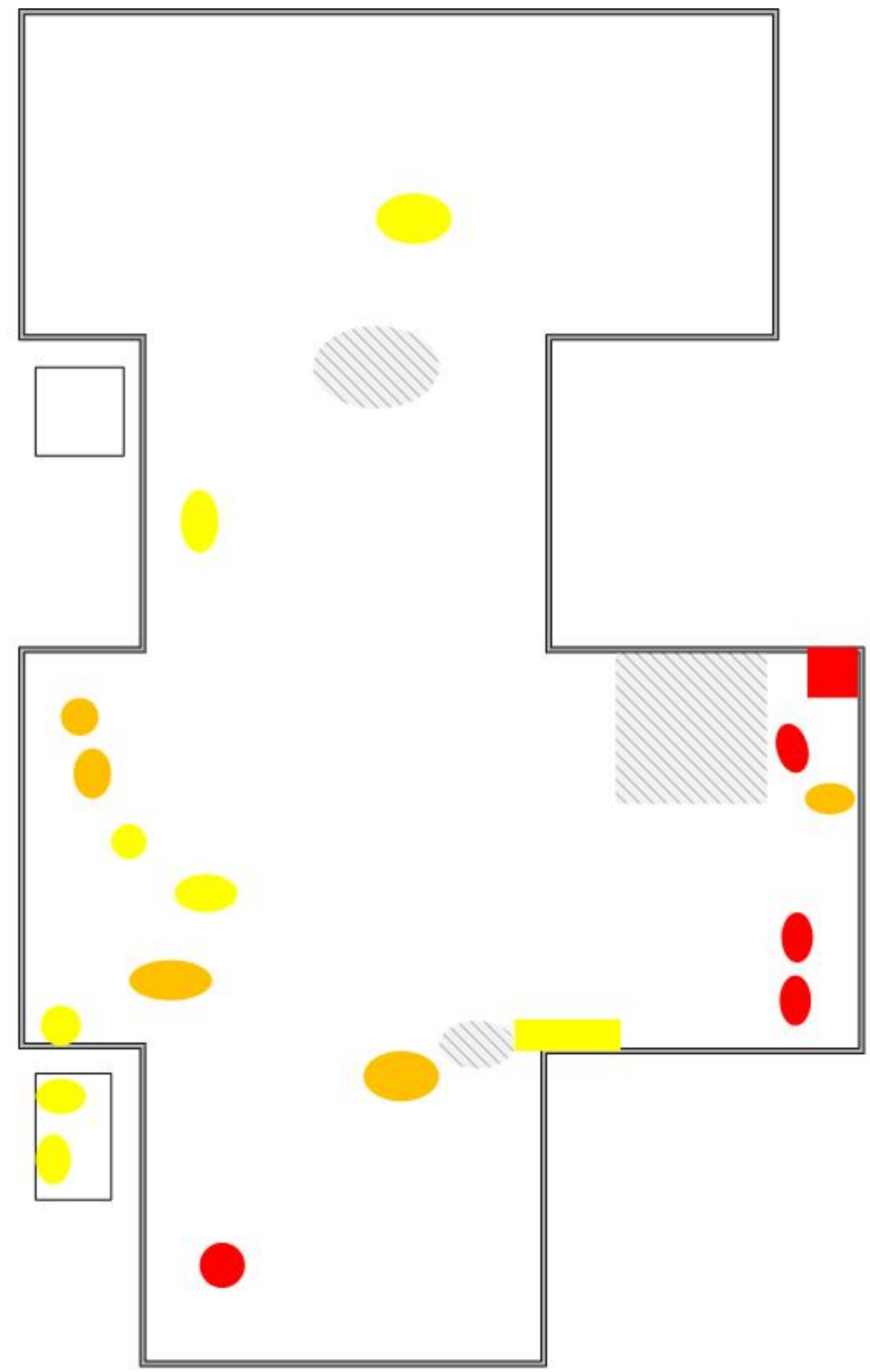

\begin{tabular}{|c|c|c|c|c|}
\hline \multicolumn{3}{|c|}{ Alpha Scan } & \multirow{3}{*}{$\underset{\mathbf{N}}{\mathbf{N}}$} & \multirow{3}{*}{$\begin{array}{c}\text { Building } 3550 \text { Slab } \\
\text { O ak Ridge National Lab }\end{array}$} \\
\hline$\bigcirc$ & $<35$ & \multirow{2}{*}{$\begin{array}{l}\text { New Concrete (Areas } \\
\text { not Scanned) }\end{array}$} & & \\
\hline 0 & $35-149 \mathrm{cpm}$ & & & \\
\hline 0 & $150-349 \mathrm{cpm}$ & \multirow{2}{*}{$\square$ Concrete Pad } & & \\
\hline & & & & Created by: Adam Kirthlink \\
\hline & $350-17,0000 \mathrm{cmm}$ & (not to scale) & & Date: $08 / 03 / 2011$ \\
\hline
\end{tabular}

Figure A-4. Building 3550 Slab Alpha Scan 


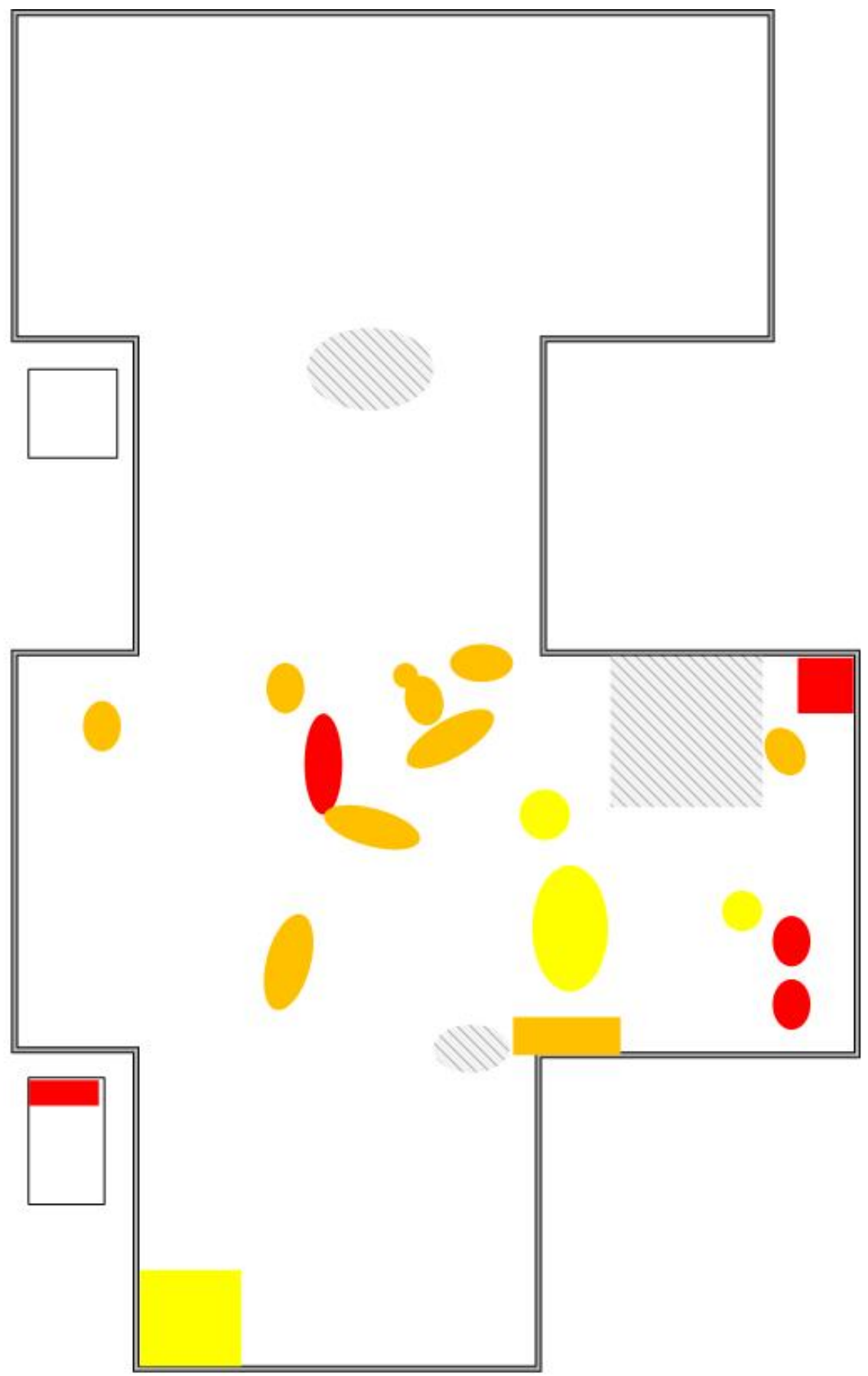

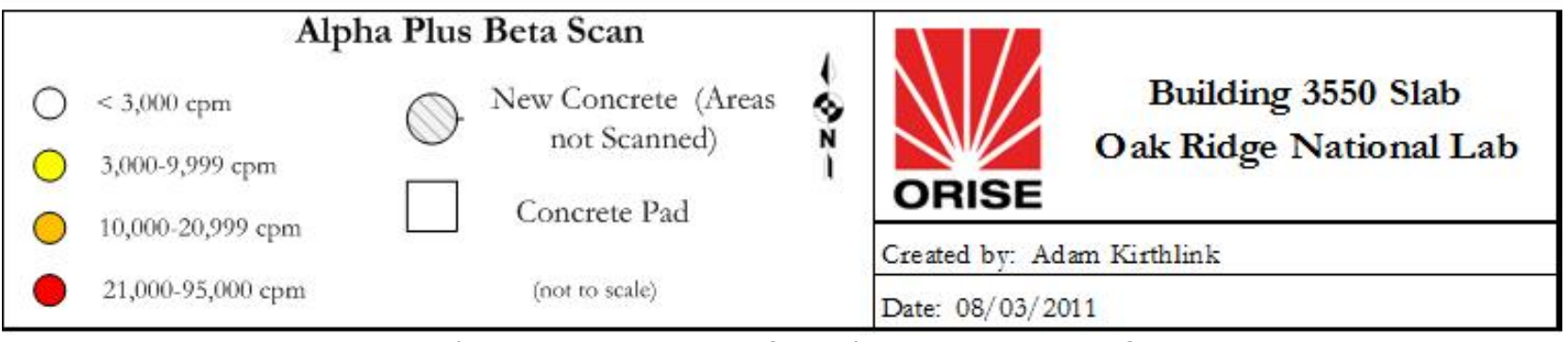

Figure A-5. Building 3550 Slab Alpha Plus Beta Scan 


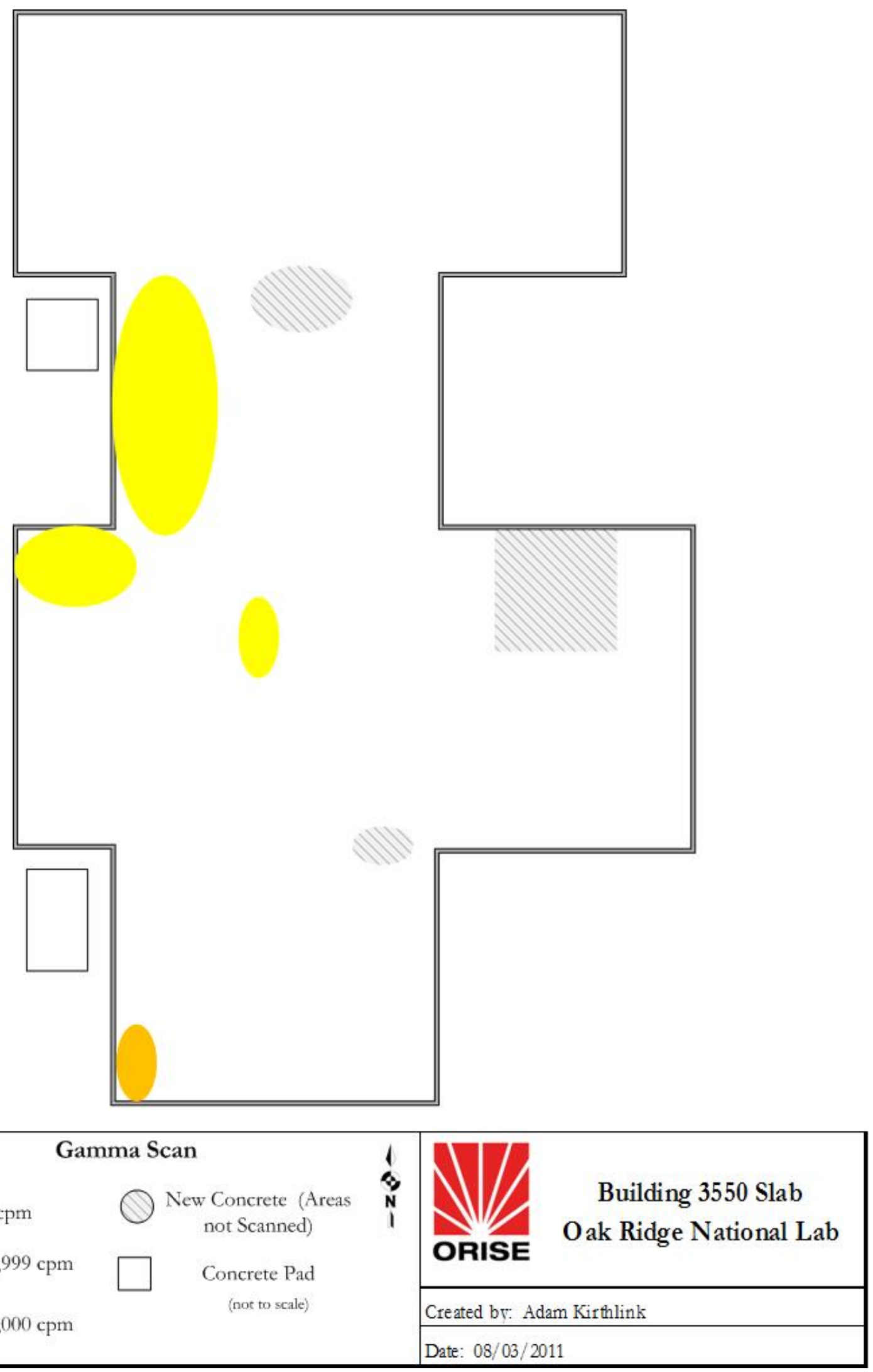

Figure A-6. Building 3550 Slab Gamma Scan 
$\triangle 5086 \mathrm{R} 0030$

$\Delta$ 5086R0029

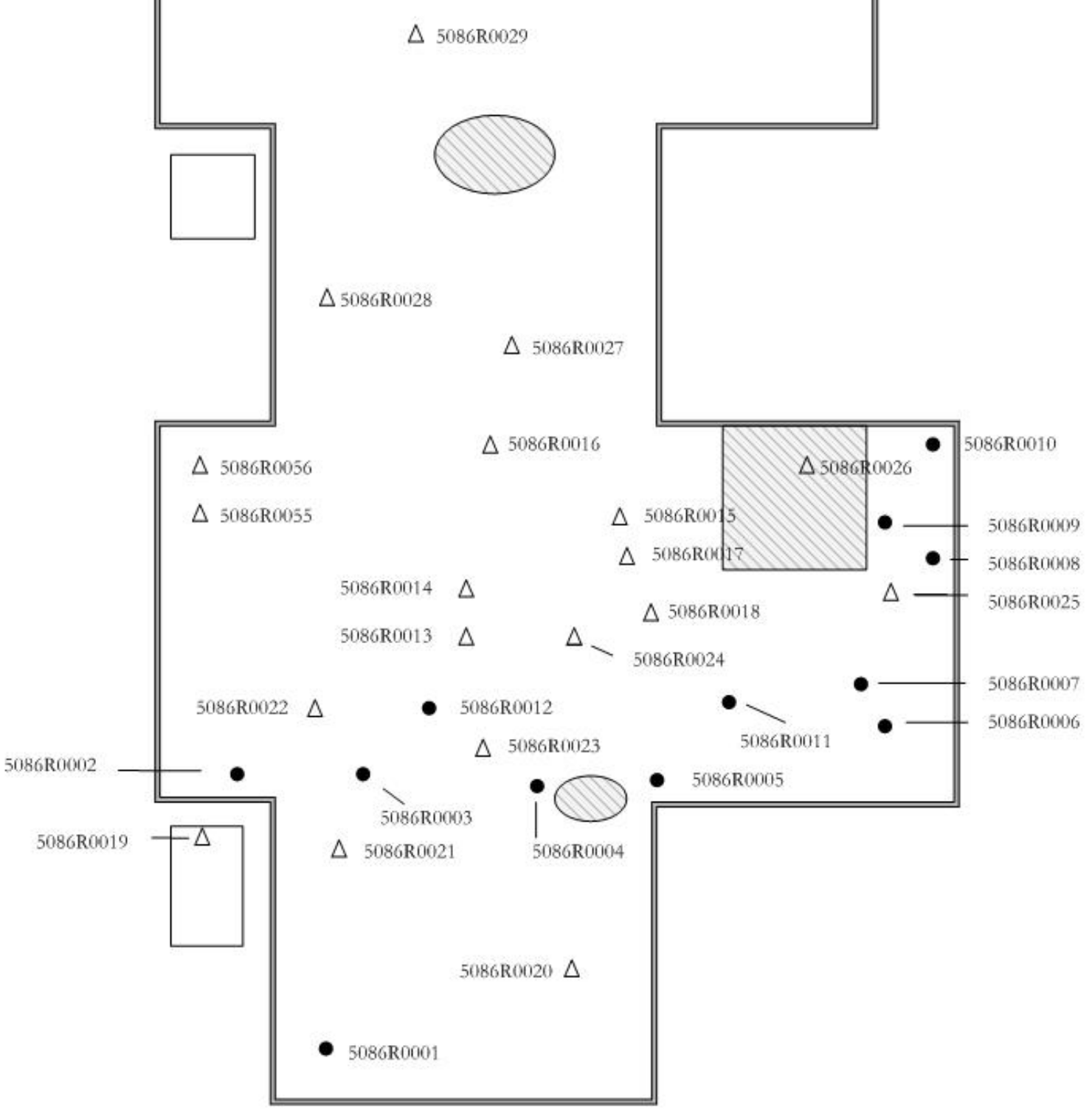

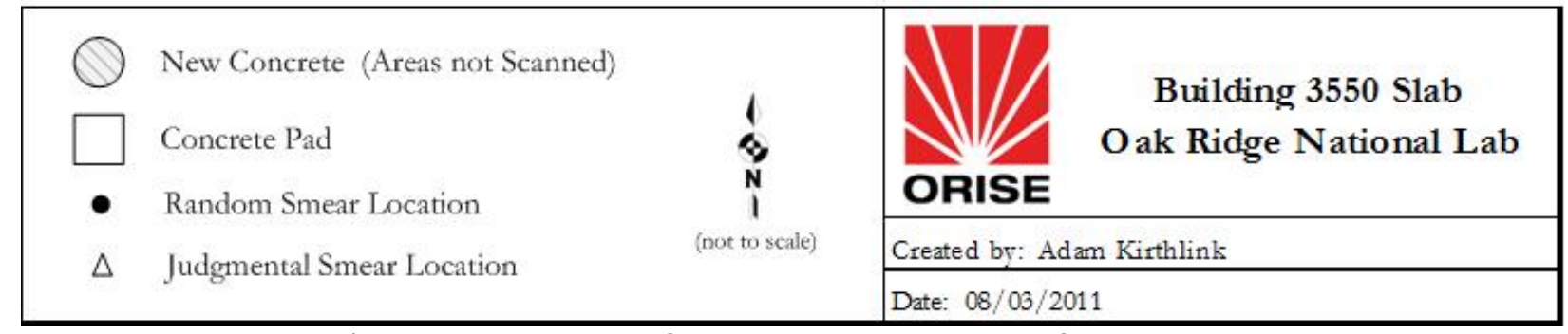

Figure A-7. Building 3550 Slab Measurement and Sample Locations 
APPENDIX B

TABLES 


\begin{tabular}{|c|c|c|c|c|c|c|}
\hline \multicolumn{7}{|c|}{$\begin{array}{c}\text { Table B-1. Surface Activity for the Building } 3550 \text { Slab } \\
\text { Oak Ridge National Laboratory } \\
\text { Oak Ridge, Tennessee }\end{array}$} \\
\hline \multirow[b]{3}{*}{$\begin{array}{l}\text { Measurement } \\
\text { and Smear } \\
\text { Location }\end{array}$} & \multicolumn{2}{|c|}{ Direct Measurements } & \multicolumn{2}{|c|}{ Direct Measurements } & \multicolumn{2}{|c|}{ Analytical Results } \\
\hline & \multicolumn{2}{|c|}{ Alpha } & \multicolumn{2}{|c|}{ Alpha + Beta } & \multicolumn{2}{|c|}{ Removable Activity } \\
\hline & $\begin{array}{l}\text { Gross } \\
\text { Activity } \\
\text { (cpm) }\end{array}$ & $\begin{array}{l}\text { Total } \\
\text { Activity } \\
(\mathrm{dpm} / \\
\left.100 \mathrm{~cm}^{2}\right)\end{array}$ & $\begin{array}{l}\text { Gross } \\
\text { Activity } \\
\text { (cpm) }\end{array}$ & $\begin{array}{l}\text { Total } \\
\text { Activity } \\
(\mathrm{dpm} / \\
\left.100 \mathrm{~cm}^{2}\right)\end{array}$ & $\begin{array}{l}\text { Alpha } \\
\text { Activity } \\
(\mathrm{dpm} / \\
\left.100 \mathrm{~cm}^{2}\right)\end{array}$ & $\begin{array}{c}\text { Beta } \\
\text { Activity } \\
(\mathrm{dpm} / \\
\left.100 \mathrm{~cm}^{2}\right)\end{array}$ \\
\hline \multicolumn{7}{|c|}{ Random Systematic Locations } \\
\hline 5086R0001 & 8 & 49 & 820 & 1,200 & 1.7 & 2.6 \\
\hline 5086R0002 & 12 & 81 & 596 & 560 & -0.4 & 4.7 \\
\hline 5086R0003 & 235 & 1,900 & 896 & 1,400 & 3.9 & -2.6 \\
\hline 5086R0004 & 398 & 3,200 & 1,327 & 2,700 & 1.7 & 0.5 \\
\hline 5086R0005 & 130 & 1,000 & 1,808 & 4,100 & 3.9 & 4.7 \\
\hline 5086R0006 & 75,166 & 610,000 & 99,378 & 290,000 & 310 & 9.9 \\
\hline 5086R0007 & 93 & 740 & 5,018 & 14,000 & 1.7 & -0.5 \\
\hline 5086R0008 & 130 & 1,000 & 1,533 & 3,300 & 1.7 & -2.6 \\
\hline 5086R0009 & 1,700 & 14,000 & 5,666 & 16,000 & 45 & 5.7 \\
\hline 5086R0010 & 650 & 5,300 & 4,170 & 11,000 & 6.1 & 1.6 \\
\hline 5086R0011 & 36 & 280 & 3,173 & 8,100 & 3.9 & -0.5 \\
\hline 5086R0012 & 76 & 600 & 5,178 & 14,000 & 1.7 & -1.6 \\
\hline \multicolumn{7}{|c|}{ Judgmental Locations } \\
\hline 5086R0013 & 57 & 450 & 18,249 & 52,000 & 1.7 & -0.5 \\
\hline 5086R0014 & 11 & 73 & 11,689 & 33,000 & 1.7 & 0.5 \\
\hline 5086R0015 & 39 & 300 & 8,876 & 25,000 & -0.4 & -2.6 \\
\hline 5086R0016 & 45 & 350 & 3,489 & 9,100 & 1.7 & 6.8 \\
\hline 5086R0017 & 12 & 81 & 3,732 & 9,800 & -0.4 & -1.6 \\
\hline 5086R0018 & 60 & 470 & 2,099 & 5,000 & 3.9 & 2.6 \\
\hline 5086R0019 & 13 & 90 & 7,672 & 21,000 & -0.4 & 2.6 \\
\hline 5086R0020 & 6 & 33 & 632 & 670 & -0.4 & -0.5 \\
\hline 5086R0021 & 8 & 49 & 659 & 750 & -0.4 & -3.6 \\
\hline 5086R0022 & 5 & 24 & 661 & 760 & 6.1 & -2.6 \\
\hline 5086R0023 & 7 & 41 & 601 & 580 & 1.7 & 1.6 \\
\hline 5086R0024 & 7 & 41 & 639 & 690 & -0.4 & 0.5 \\
\hline 5086R0025 & 20 & 150 & 642 & 700 & -0.4 & -0.5 \\
\hline 5086R0026 & 7 & 41 & 550 & 430 & -0.4 & -3.6 \\
\hline 5086R0027 & 7 & 41 & 635 & 680 & -0.4 & 2.6 \\
\hline 5086R0028 & 7 & 41 & 843 & 1,300 & 1.7 & 3.6 \\
\hline 5086R0029 & 10 & 65 & 708 & 900 & -0.4 & -4.7 \\
\hline 5086R0030 & 4 & 16 & 552 & 430 & -0.4 & -1.6 \\
\hline 5086R0031 & 12 & 81 & 610 & 610 & 1.7 & 0.5 \\
\hline 5086R0055 & 91 & 720 & 1,462 & 3,100 & 19 & 7.8 \\
\hline 5086R0056 & 320 & 2,600 & 7,632 & 21,000 & 28 & 19 \\
\hline
\end{tabular}


APPENDIX C

MAJOR INSTRUMENTATION 


\section{C.1 SCANNING AND MEASUREMENT INSTRUMENT/DETECTOR COMBINATIONS}

\section{C.1.1 Alpha Plus Beta}

Ludlum Floor Monitor Model 239-1

combined with

Ludlum Ratemeter-Scaler Model 2221

coupled to Ludlum Gas Proportional Detector Model 43-37, Physical Area: $550 \mathrm{~cm}^{2}$

(Ludlum Measurements, Inc., Sweetwater, TX)

\section{C.1.2 GAMMA}

Ludlum NaI Scintillation Detector Model 44-10, Crystal: $5.1 \mathrm{~cm}$ x $5.1 \mathrm{~cm}$

(Ludlum Measurements, Inc., Sweetwater, TX)

coupled to:

Ludlum Ratemeter-scaler Model 2221

(Ludlum Measurements, Inc., Sweetwater, TX)

\section{C.2 DIRECT MEASUREMENT INSTRUMENT/DETECTOR COMBINATIONS}

\section{C.2.1 AlPHA AND BETA}

Ludlum Ratemeter-Scaler Model 2221

coupled to

Ludlum Gas Proportional Detector Model 43-68, Physical Area: $126 \mathrm{~cm}^{2}$

(Ludlum Measurements, Inc., Sweetwater, TX)

\section{C.3 LABORATORY ANALYTICAL INSTRUMENTATION}

Low background alpha/beta counting system

Canberra/Tennelec LB5100W Eclipse Software

(Canberra, Inc., Meriden, CT) 
APPENDIX D

SURVEY AND ANALYTICAL PROCEDURES 


\section{D.1 PROJECT HEALTH AND SAFETY}

Survey activities were conducted in accordance with the ORAU/ORISE overall health and safety program (HASP) and radiological protection program manuals (ORAU 2011b and ORISE 2011c). Pre-survey activities included an overview of potential health and safety issues. Potential health and safety issues that were identified were appropriately addressed by the ORISE HASP, site-specific Integrated Safety Management (ISM) pre-job hazard checklist, and an activity hazard analysis (AHA) prior to beginning site work.

\section{D.2 QUALITY ASSURANCE}

Analytical and field survey activities were conducted in accordance with procedures from the following ORAU and ORISE documents:

- Survey Procedures Manual (ORISE 2008)

- Laboratory Procedures Manual (ORISE 2011b)

- Quality Program Manual (ORAU 2011)

The procedures contained in these manuals were developed to meet the requirements of 10 CFR 830 Subpart A, Quality Assurance Requirements, Department of Energy Order 414.1C, Quality Assurance, and the U.S. Nuclear Regulatory Commission, Quality Assurance Manual for the Office of Nuclear Material Safety and Safeguards, and contain measures to assess processes during their performance.

Quality control procedures include:

- Daily instrument background and check-source measurements to confirm that equipment operation is within acceptable statistical fluctuations.

- Participation in Mixed Analyte Performance Evaluation Program (MAPEP), National Institute for Standards and Technology (NIST) Radiochemistry Intercomparison Program (NRIP), and Intercomparison Testing Program (ITP) Laboratory Quality Assurance Programs.

- Training and certification of all individuals performing procedures.

- Periodic internal and external audits. 


\section{D.3 CALIBRATION}

Detectors used for assessing surface activity were calibrated in accordance with ISO-7503 ${ }^{1}$ recommendations. Total alpha and beta efficiencies $\left(\boldsymbol{\varepsilon}_{\text {total }}\right)$ were determined for each instrument/detector combination and consisted of the product of the $2 \pi$ instrument efficiency $\left(\varepsilon_{i}\right)$ and surface efficiency $\left(\varepsilon_{\mathrm{s}}\right): \varepsilon_{\mathrm{total}}=\varepsilon_{\mathrm{i}} \times \varepsilon_{\mathrm{s}}$. Beta total efficiencies were determined based on a beta energy multi-point calibration, development of instrument efficiency to beta energy calibration curves, and the calculation of the weighted efficiency representing the Th-232 decay series. Included in the weighted efficiency was an empirically determined correction for disequilibrium in the decay series that results from $\mathrm{Rn}-220$ loss. A $3.8 \mathrm{mg} / \mathrm{cm}^{2}$ density thickness mylar window was used on the beta detectors to block detector response contributions from alpha radiation.

Th-230 was selected as the alpha calibration source. The $2 \pi$ alpha instrument efficiency $\left(\varepsilon_{i}\right)$ factor was 0.39 for the gas proportional detector. C-14, Tc-99, Tl-204, and Sr/Y-90 were selected as the beta calibration sources to represent the energy distribution of the detectable beta-emitters in the Th-232 decay series. The $2 \pi$ interpolated $\varepsilon_{\mathrm{i}}$ factors for the detectable beta-emitters ranged from 0.34 to 0.56 for the gas proportional detector. ISO-7503 recommends an $\varepsilon_{\mathrm{s}}$ of 0.25 for alpha emitters and also beta emitters with a maximum energy of less than $0.4 \mathrm{MeV}$ and an $\varepsilon_{\mathrm{s}}$ of 0.5 for maximum beta energies greater than $0.4 \mathrm{MeV}$. The thorium series alpha efficiency is 0.10 . The total weighted beta efficiency for the beta detectors ranged from 0.08 to 0.28 .

Calibration of all field and laboratory instrumentation was based on standards/sources, traceable to NIST, when such standards/sources were available. In cases where they were not available, standards of an industry-recognized organization were used.

\section{D.4 SURVEY PROCEDURES}

\section{D.4.1 SURFACE SCANS}

Scans for elevated gamma radiation were performed by passing the detector slowly over the surface, the distance between the detector and the surface was maintained at a minimum—nominally about 1 $\mathrm{cm}$ or as close to the surface as possible. A NaI scintillation detector was used to scan for elevated gamma radiation throughout the slab. The scan minimum detectable concentrations (MDCs) for the

${ }^{1}$ International Standard. ISO 7503-1, Evaluation of Surface Contamination - Part 1: Beta-emitters (maximum beta energy greater than $0.15 \mathrm{MeV}$ ) and alpha-emitters. August 1, 1988. 
$\mathrm{NaI}$ scintillation detector for the contaminants of concern for a concrete surface were obtained directly from NUREG- $1507^{2}$ when available or estimated using the calculation approach described in NUREG-1507. A typical NaI 2-in x 2-in detector MDC is $6.4 \mathrm{pCi} / \mathrm{g}$ for cesium-137. Audible increases in the activity rate are investigated by ORISE. It is standard procedure for ORISE staff to pause and investigate any locations where gamma radiation is distinguishable from background levels.

\section{D.4.2 Surface ACTIVITY MEASUREMENTS}

Measurements of total alpha and total beta surface activity levels were performed using hand-held scintillation detectors coupled to portable ratemeter-scalers. Count rates (cpm), which were integrated over one minute with the detector held in a static position, were converted to activity levels $\left(\mathrm{dpm} / 100 \mathrm{~cm}^{2}\right)$ by dividing the count rate by the total static efficiency $\left(\varepsilon_{\mathrm{i}} \times \varepsilon_{\mathrm{s}}\right)$ and correcting for the physical area of the detector.

The a priori MDC for surface activity measurements was calculated using the following equation:

Where:

$$
M D C=\frac{3+(4.65 \sqrt{B})}{T x \varepsilon_{T o t} x G}
$$

$\begin{array}{lll}\mathrm{B} & = & \text { background (total counts) in time interval, T } \\ \mathrm{T} & = & \text { count time (min) used for field instruments } \\ \varepsilon_{\mathrm{Tot}} & = & \text { total efficiency }=\varepsilon_{\mathrm{i}} \times \varepsilon_{\mathrm{s}} \\ \varepsilon_{\mathrm{i}} & = & \text { instrument efficiency } \\ \varepsilon_{\mathrm{s}} & = & \text { source efficiency } \\ \mathrm{G} & = & \left.\text { geometry (physical detector area } \mathrm{cm}^{2} / 100\right)\end{array}$

The a priori alpha static MDC was approximately $76 \mathrm{dpm} / 100 \mathrm{~cm}^{2}$ using the total efficiency of 0.10 and an instrument background of $2 \mathrm{cpm}$. The physical surface area assessed by the scintillation detector used was $100 \mathrm{~cm}^{2}$. The a priori beta static MDC was approximately $284 \mathrm{dpm} / 100 \mathrm{~cm}^{2}$ using the total efficiency of 0.27 and the nominal instrument background of $404 \mathrm{cpm}$. The physical surface area assessed by the detector used was $126 \mathrm{~cm}^{2}$.

\footnotetext{
${ }^{2}$ NUREG-1507. Minimum Detectable Concentrations With Typical Radiation Survey Instruments for Various
} Contaminants and Field Conditions. U.S. Nuclear Regulatory Commission. Washington, DC; June 1998. 


\section{D.4.3 Removable ACtivity MEASUREMENTS}

Smear samples for removable gross alpha and gross beta contamination were obtained from each measurement location. Removable activity samples were collected using numbered filter paper disks, $47 \mathrm{~mm}$ in diameter. Moderate pressure was applied to the smear and approximately $100 \mathrm{~cm}^{2}$ of the surface was wiped. Smears were placed in labeled envelopes with the location and other pertinent information recorded.

\section{D.5 RADIOLOGICAL ANALYSIS}

\section{D.5.1 Gross AlPha/BETA}

Smears were counted on a low-background gas proportional system for gross alpha and beta activity. The MDCs of the procedure were $9 \mathrm{dpm} / 100 \mathrm{~cm}^{2}$ and $15 \mathrm{dpm} / 100 \mathrm{~cm}^{2}$ for a 2 -minute count time for gross alpha and gross beta, respectively.

\section{D.5.2 Detection Limits}

Detection limits, referred to as MDC, were based on 3 plus 4.65 times the standard deviation of the background $(\mathrm{BKG})$ count $\left[3+\left(4.65(\mathrm{BKG})^{1 / 2}\right)\right]$. Because of variations in background levels, measurement efficiencies, and contributions from other radionuclides in samples, the detection limits differ from sample to sample and instrument to instrument. 